\title{
Diversity and phylogenetic relationships of European species of Crepidostomum Braun, 1900 (Trematoda: Allocreadiidae) based on rDNA, with special reference to Crepidostomum oschmarini Zhokhov \& Pugacheva, 1998
}

Romualda Petkevičiūtè ${ }^{*}$, Virmantas Stunžènas ${ }^{1}$, Alexander E. Zhokhov², Larisa G. Poddubnaya ${ }^{2}$ and Gražina Stanevičiūtè ${ }^{1}$

\begin{abstract}
Background: Within the genus Crepidostomum Braun, 1900, identification of species and taxonomic decisions made only on the basis of adult morphology have resulted in great problems associated with evaluating actual diversity and validity of species. Life-cycle data, while equal in importance to adult characters, are scarce, controversial or incomplete for most Crepidostomum spp. In this study, rDNA sequences generated from adult and larval Crepidostomum spp. and some other allocreadiid species were analysed to reveal the diversity and phylogenetic relationships of the species and their host range. Detailed morphological description based on light microscopy, SEM tegumental surface topography and genetic data are provided for the poorly known trematode C. oschmarini Zhokhov \& Pugacheva, 1998 found in the intestine of two teleost fish species, Barbatula barbatula (L.) and Cottus gobio L.

Results: We characterized 27 isolates of adult and larval parasites. Based on newly obtained 285 and ITS1-5.8S-ITS2 rDNA sequences, new intermediate and final hosts were ascertained, and life-cycles clarified for some allocreadiids. New knowledge on the diversity and phylogenetic relationships of European Crepidostomum spp. was gained. The validity of $C$. oschmarini was verified based on comparative sequence analysis. Ophthalmoxiphidiocercariae of $C$. oschmarini were recorded in sphaeriid bivalves Pisidium (Euglesa) casertanum (Poli). Additionally, morphological differences between gravid specimens of C. oschmarini and other related species were observed.

Conclusions: Species of the Allocreadiidae parasitizing fishes in Europe are distributed among two monophyletic genera, Allocreadium and Bunodera, and two paraphyletic Crepidostomum clades. A complex of Crepidostomum metoecus (syn. C. nemachilus), C. oschmarini and Crepidostomum sp. 2 clustered in one clade, and a complex of $C$. farionis, Crepidostomum sp. 1 and, probably, C. wikgreni in the other. Molecular data indicated that C. oschmarini and Crepidostomum sp. 2 presumably have a wide geographical distribution in Europe. The new data provided evidence that Crepidostomum is a more diverse genus than can be judged from morphological data and host switching in this genus may occur independently of fish-host phylogeny.
\end{abstract}

Keywords: Crepidostomum oschmarini, ITS2 rDNA, 28S, Molecular phylogeny, Life-cycles, Tegumental topography, Morphology, Stone loach Barbatula barbatula, European bullhead Cottus gobio

\footnotetext{
* Correspondence: romualda.petkeviciute@gamtc.lt

${ }^{1}$ Institute of Ecology of Nature Research Centre, Akademijos str. 2, LT-08412

Vilnius, Lithuania

Full list of author information is available at the end of the article
}

(c) The Author(s). 2018 Open Access This article is distributed under the terms of the Creative Commons Attribution 4.0 International License (http://creativecommons.org/licenses/by/4.0/), which permits unrestricted use, distribution, and reproduction in any medium, provided you give appropriate credit to the original author(s) and the source, provide a link to the Creative Commons license, and indicate if changes were made. The Creative Commons Public Domain Dedication waiver (http://creativecommons.org/publicdomain/zero/1.0/) applies to the data made available in this article, unless otherwise stated. 


\section{Background}

Trematodes of the genus Crepidostomum Braun, 1900 are common parasites in the intestine of freshwater teleosts in the Holarctic $[1,2]$. Including many nominal species, the taxonomy of this genus still lacks clarity and the actual diversity and validity of some species is still questioned. Although most taxonomic decisions have been made based on adult morphology, it should be noted that a number of species are morphologically very similar and there exist only a few morphological features useful for distinguishing species [3, 4]. Crepidostomum farionis (Müller, 1784) and C. metoecus Braun, 1900 are among the most common and widely distributed freshwater parasites of salmonid fishes in Europe. Occasionally they are also found in Cottus spp. (Cottidae), Barbatula barbatula (L.) (Nemacheilidae) and some other fishes [5-7]. Reliable features for differentiating these two species were obtained only in the second half of the 20th century (see [7]) and formerly $C$. metoecus was frequently mistaken for C. farionis. Additionally, both species have been known by numerous synonyms (see [1, 8]). Prior to the present study, C. farionis and $C$. metoecus were the only representatives of the genus to have been recorded in Lithuania and neighboring regions $[6,9]$.

Crepidostomum oschmarini Zhokhov \& Pugacheva, 1998 was described from the stone loach Barbatula barbatula (as Nemacheilus barbatulus) (Nemacheilidae) from the small Sutki River in the upper Volga River basin, Russia [10]. Later, the validity of this species was questioned based on a comparative study of the morphological variability of Crepidostomum spp., and $C$. oschmarini was synonymized with C. metoecus [11]. However, the definitive hosts of C. metoecus (salmonid fishes), have never been found in the Sutki River and the exact taxonomic status of $C$. oschmarini remained unresolved. Here, we re-visit the taxonomic status of $C$. oshmarini based on material from a new host, the European bullhead Cottus gobio (Cottidae, Scorpaeniformes), collected in the Il'd River, Russia. The main purpose of this study was to gain new knowledge on the diversity and phylogenetic relationships of European Crepidostomum spp. and to determine whether $C$. oschmarini and $C$. metoecus are distinct or synonymous by comparing the 5.8S-ITS2 rDNA cluster and partial $28 S$ rDNA gene sequences, as well as to investigate the phylogenetic relationships of $C$. oschmarini within the Allocreadiidae. In addition to the molecular evidence provided, a detailed morphological study of C. oschmarini based on light and scanning electron microscopy (SEM) was accomplished. Despite the small number of studies on SEM morphology of Crepidostomum spp. it has been demonstrated that some surface features, such as the distribution of sensory endings, may provide additional specific characters for their identification $[1,7,12,13]$.
Life-cycle data and larval characters are equal in importance to adult characters for resolving some difficulties in taxonomy $[1,14]$. Unfortunately, data for cercariae are lacking or incomplete for most 'recognized' Crepidostomum species [1]. Bivalves rather than gastropods are utilized as first intermediate hosts [2]. Known allocreadiid cercariae belong to the ophthalmoxiphidiocercariae type (i.e. with eye-spots and stylet) and develop in rediae [2]. The development of Crepidostomum farionis was elucidated by Brown [15]. Larval stages of $C$. metoecus were studied and described by Stenko [16] in Crimea (River Burulcha). The sphaeriid clam Pisidium (Euglesa) casertanum (Poli) was recorded as the first intermediate host, while larvae of the ephemeropteran Ameletus sp. served as the second intermediate host in experimental infection. Meanwhile, Awachie [17] found that the gastropod Radix peregra (O. F. Müller) (as Lymnaea peregra) serves as the first intermediate host for $C$. metoecus in North Wales and cercariae encysted in the amphipod Gammarus pulex (L.) as the second intermediate host (cercariae of allocreadiids encyst in aquatic arthropods). Due to this discrepancy between the two studies, it is likely that the authors were in fact dealing with different species.

The identification of intramolluscan stages of trematodes using morphological characters alone is difficult given their overall body plasticity and small size in relation to their complexity. The descriptions of cercariae of many related species render them morphologically indistinguishable. With molecular genetic methods having become standard practice for parasite identification, molecular data have become essential for matching different stages of digenean life-cycles. However, not a single life-cycle of a Crepidostomum species has been proven by molecular methods and only recently has a molecular study on trematodes in a sub-Arctic lake provided some molecular data on the diversity of developmental stages of some Crepidostomum spp. and their hosts in Europe [18].

During a parasite study of sphaeriid bivalves collected from different populations in Lithuania, Crimea and Norway, we found clams naturally infected with rediae and ophthalmoxiphidiocercariae consistent with the diagnosis and descriptions for allocreadiid cercariae. In the present study, rDNA markers of larval and adult allocreadiid stages were obtained and compared to known rDNA markers available for allocreadiid trematodes with the aim to clarify life-cycles, host specificity and phylogenetic relationships.

\section{Methods}

Adult specimens of $C$. oschmarini were recovered from the intestine of B. barbatula and $C$. gobio. The fish hosts were caught in the Il'd River in the upper Volga River basin, Russia. Specimens of a few other adult allocreadiids, 
i.e. Allocreadium isoporum (Looss, 1894), Bunodera luciopercae (Müller, 1776) and Crepidostomum sp. 1 sensu Soldánová et al. (2017) [18], were recovered from fish hosts in Lithuania and Norway. Naturally infected sphaeriid clams were collected from different freshwater bodies in Lithuania, Norway and Crimea using hand-nets. The developmental stages of the allocreadiid species used in this study, their hosts, their sampling locality, and the GenBank accession numbers for the corresponding sequences, are presented in the Table 1.

Adult trematodes were collected live from freshly killed fish. For molecular studies, the worms were rinsed in saline before being stored at $4{ }^{\circ} \mathrm{C}$ in $96 \%$ ethanol. Subsamples of the material for the morphological studies were fixed live in hot $10 \%$ buffered formalin. A total of 25 adult and gravid specimens of C. oschmarini (15 specimens from B. barbatula and 10 from C. gobio) were used for light microscopy examination. All measurements are in micrometres and are given as the range followed by the mean in parentheses.

For scanning electron microscopy, 19 live specimens of C. oschmarini from B. barbatula were fixed in $2.5 \%$ glutaraldehyde in $0.1 \mathrm{M}$ phosphate buffer ( $\mathrm{pH}$ 7.3) for 15 days at $4{ }^{\circ} \mathrm{C}$. After washing in phosphate buffer, fixed worms were dehydrated though a graded ethanol series and acetone. They were then critical-point dried with liquid $\mathrm{CO}_{2}$ and mounted on stubs, sputter-coated with gold-palladium and examined using a JEOL JSM 6510LV scanning electron microscope (SEM) operating at $30 \mathrm{kV}$.

Genomic DNA was extracted from individual ethanolfixed specimens following the protocol of Stunženas et al. [19] with a slight modification described in Petkevičiūte et al. [20]. DNA fragments spanning the 3' end of the $5.8 S$ rRNA gene, the complete internal transcribed spacer 2 region (ITS2) and a small section at the $5^{\prime}$ end of the $28 \mathrm{~S}$ gene were amplified using universal primers for flatworms, the forward primer 3S (5'-CGG TGG ATC ACT CGG CTC GTG-3') [21] and the reverse primer ITS2.2 (5'-CCT GGT TAG TTT CTT TTC CTC CGC-3') [22]. Using a new primer pair designed for species of the Allocreadiidae, the end of the internal transcribed spacer 1 (ITS1), the complete 5.8S rDNA and ITS2, also a small section at the $5^{\prime}$ end of the $28 S$ gene were amplified using the forward primer AlJe-F (5'-GTC TGG CTT GGC AGT TCT A-3') and the reverse primer AlJe-R (5'-CTG CCC AAT TTG ACC AAG C-3'). A fragment at the $5^{\prime}$ end of the $28 S$ rRNA gene was amplified using the forward primers Digl2 (5'-AAG CAT ATC ACT AAG CGG-3') or ZX-1 (5'-ACC CGC TGA ATT TAA GCA TAT-3') [23] and the reverse primers L0 (5'-GCT ATC CTG AG (AG) GAA ACT TCG-3') [24] or 1500R (5'-GCT ATC CTG AGG GAA ACT TCG-3') $[25,26]$. Amplification protocols are as described in Petkevičiūte et al. [20]. The amplification protocol for the newly designed primers AlJe-F and AlJe-R is identical as for the primer pair Digl2-L0. PCR products were purified and sequenced in both directions at BaseClear B.V. (Leiden, Netherlands) using the PCR primers. Contiguous sequences were assembled using Sequencher 4.7 software (Gene Codes Corporation, Ann Arbor, USA). Sequences generated in this study have been deposited in the GenBank database (see accession numbers in Table 1).

Additional rDNA sequences for species of the Allocreadiidae and outgroup taxa (Table 1) were downloaded from GenBank and included in pairwise sequence comparisons and phylogenetic analyses. For phylogenetic analyses, the sequences were aligned using multiple sequence alignment software MAFFT version 7 [27] with iterative refinement method of G-INS-i. The best-fit model of sequence evolution for phylogenetic analysis was estimated using jModeltest v.0.1.1 software [28]. Maximum likelihood (ML) phylogenetic trees were obtained and analyzed using MEGA v.6 [29]. Branch support was estimated by bootstrap analyses with 1000 pseudoreplicates. The ML trees were obtained using the general time reversible model with a gamma distribution rate and a proportion of invariant sites $(G T R+G+I)$ for both the ITS2 and the $28 S$ gene datasets. Gamma shape and the number of invariant sites were estimated from the data. Parsimony analysis based on subtree pruning and regrafting (SPR) was used with default parsimony settings. If two or more sequences belonged to one species, they were collapsed into one branch, except those newly obtained in this study. Estimates of mean evolutionary divergence over sequence pairs within and between groups were calculated using MEGA v.6.

\section{Results \\ Family Allocreadiidae Looss, 1902 \\ Genus Crepidostomum Braun, 1900}

Crepidostomum oschmarini Zhokhov \& Pugacheva, 1998

Type-host: Barbatula barbatula (L.) (Cypriniformes: Nemacheilidae).

Other host: Cottus gobio L. (Scorpaeniformes: Cottidae). Type-locality: River Sutki, Il'd River (the upper Volga River basin), Russia.

Site in host: Intestine.

First intermediate host: Pisidium (Euglesa) casertanum (Poli) (Veneroida: Sphaeriidae).

Voucher material: Four voucher specimens ex C. gobio on 2 slides [No. 1/9(6-7)] and 6 voucher specimens ex B. barbatula on 2 slides [(No. 1/9(10-11)] were deposited in the Parasite Collection of the Institute for Biology of Inland Waters RAS, Russia. 
Table 1 Species subjected to molecular phylogenetic analysis with information for hosts, localities and GenBank accession numbers

\begin{tabular}{|c|c|c|c|c|}
\hline \multirow[t]{2}{*}{ Species } & \multirow[t]{2}{*}{ Host } & \multirow[t]{2}{*}{ Locality } & \multicolumn{2}{|l|}{ GenBank ID ${ }^{\mathrm{b}}$ [Reference] } \\
\hline & & & 285 & ITS2 \\
\hline $\begin{array}{l}\text { Allocreadium sp. }{ }^{\text {a }} \\
\text { (= Crepidostomum sp.) }\end{array}$ & Sphaerium corneum & $\begin{array}{l}\text { Ukraine: River Belka, Dnieper River } \\
\text { basin }\end{array}$ & GU462121 [44] & FJ874919 [44] \\
\hline Allocreadium sp. ${ }^{a}$ & Pisidium amnicum & $\begin{array}{l}\text { Russia: River Tvertsa, upper Volga } \\
\text { River basin }\end{array}$ & & FJ874923 [44] \\
\hline Allocreadium gotoi & $\begin{array}{l}\text { Misgurnus } \\
\text { anguillicaudatus }\end{array}$ & Japan: Nagano, liyama, Midori & LC215274 [61] & \\
\hline Allocreadium isoporum & Alburnus alburnus & Russia: Lake Oster, Karelia & $\begin{array}{l}\text { GU462125, GU462126 } \\
{[44]}\end{array}$ & FJ874921 [44] \\
\hline Allocreadium isoporum & Barbatula barbatula & $\begin{array}{l}\text { Russia: River Il'd, upper Volga } \\
\text { River basin }\end{array}$ & MH143102 & MH143096 \\
\hline Allocreadium lobatum & Semotilus corporalis & USA: Moosehead Lake, Maine & EF032693 [62] & \\
\hline Allocreadium neotenicum & Hydroporus rufifrons & $\begin{array}{l}\text { United Kingdom: Lake District, } \\
\text { Cumbria }\end{array}$ & JX977132 [43] & \\
\hline Allocreadium neotenicum & Oreodytes sanmarkii & Norway: Lake Takvatn & KY513133 [18] & \\
\hline Allocreadium neotenicum ${ }^{a}$ & Pisidium casertanum & Ukraine: River Burulcha, Crimea & MH143103 & MH143075 \\
\hline Allocreadium neotenicum ${ }^{a}$ & P. casertanum & Norway: Lake Takvatn & MH143104 & MH143076 \\
\hline Allocreadium neotenicum ${ }^{a}$ & Pisidium sp. & Norway: Lake Nordersjoen & MH143105 & MH143077 \\
\hline Auriculostoma sp. & Astyanax mexicanus & Mexico: Filipinas, Veracruz & & KF631425, KF631426 [63] \\
\hline Auriculostoma astyanace & Astyanax aeneus & $\begin{array}{l}\text { Costa Rica: Tempisquito River, } \\
\text { Guanacaste }\end{array}$ & HQ833707 [64] & \\
\hline Auriculostoma lobata & Brycon guatemalensis & Mexico: Mangal Lagoon, Tabasco & KX954172 [51] & \\
\hline Bunodera sp. & Perca flavescens & USA: Steamboat Lake & HQ833704 [64] & \\
\hline Bunodera acerinae & $\begin{array}{l}\text { Gymnocephalus } \\
\text { cernuus }\end{array}$ & Russia: Lake Segozero, Karelia & GU462114 [44] & FJ874914 [44] \\
\hline Bunodera acerinae $e^{a}$ & P. amnicum & $\begin{array}{l}\text { Russia: River Tvertsa, upper Volga } \\
\text { River basin }\end{array}$ & $\begin{array}{l}\text { GU462112, GU462113, } \\
\text { GU462122 [44] }\end{array}$ & FJ874911 [44] \\
\hline Bunodera luciopercae & Perca fluviatilis & Lithuania: Curonian Lagoon & MH143101 & MH143097 \\
\hline Bunodera luciopercae & P. fluviatilis & Russia: Lake Segozero, Karelia & GU462115 [44] & FJ874917 [44] \\
\hline Bunodera luciopercae & P. fluviatilis & $\begin{array}{l}\text { Russia: River Tvertsa, upper Volga } \\
\text { River basin }\end{array}$ & GU462123 [44] & FJ874918 [44] \\
\hline Bunodera luciopercae $e^{a}$ & Sphaerium rivicola & $\begin{array}{l}\text { Lithuania: dammed up River } \\
\text { Nemunas near Kaunas }\end{array}$ & GU462116 [44] & FJ874916 [44] \\
\hline Bunodera luciopercae $e^{a}$ & S. rivicola & Ukraine: River Teterev & GU462111 [44] & FJ874915 [44] \\
\hline Cercariaeum crassum $^{\text {a }}$ & P. amnicum & Lithuania: River Ūla & GU462120 [65] & $J F 261148[65]$ \\
\hline Crepidostomum sp. $1^{\mathrm{a}}$ & Sphaerium sp. & Norway: Lake Takvatn & KY513149 [18] & \\
\hline Crepidostomum sp. $1^{\text {a }}$ & Siphlonurus lacustris & Norway: Lake Takvatn & KY513150 [18] & \\
\hline Crepidostomum sp. 1 & Salmo trutta & Norway: Lake Sagelvvatn & MH143111, MH143112 & MH143080, MH143082 \\
\hline Crepidostomum sp. $1^{\mathrm{a}}$ & P. casertanum & Norway: Lake Sagelvvatn & MH143113, MH143114 & $\begin{array}{l}\text { MH143078, MH143081, } \\
\text { MH143086 }\end{array}$ \\
\hline Crepidostomum sp. $1^{\text {a }}$ & Pisidium sp. & Norway: Lake Sagelvvatn & MH143107, MH143108 & MH143084, MH143085 \\
\hline Crepidostomum sp. $1^{\mathrm{a}}$ & Sphaerium nitidum & Norway: Lake Kykkelvatn & $\begin{array}{l}\text { MH143106, MH143109, } \\
\text { MH143110 }\end{array}$ & MH143079, MH143083 \\
\hline Crepidostomum sp. $2^{\mathrm{a}}$ & P. casertanum & Ukraine: River Burulcha, Crimea & $\begin{array}{l}\text { MH143117, MH143118, } \\
\text { MH143119 }\end{array}$ & $\begin{array}{l}\text { MH143098, MH143099, } \\
\text { MH143100 }\end{array}$ \\
\hline Crepidostomum sp. $2^{\mathrm{a}}$ & P. casertanum & Norway: Lake Sagelvvatn & MH143115, MH143116 & $\begin{array}{l}\text { MH143087, MH143088, } \\
\text { MH143089 }\end{array}$ \\
\hline Crepidostomum sp. 2 & S. trutta & Norway: Lake Takvatn & KY513154 [18] & \\
\hline Crepidostomum sp. 2 & S. lacustris & Norway: Lake Takvatn & KY513151 [18] & \\
\hline
\end{tabular}


Table 1 Species subjected to molecular phylogenetic analysis with information for hosts, localities and GenBank accession numbers (Continued)

\begin{tabular}{|c|c|c|c|c|}
\hline \multirow[t]{2}{*}{ Species } & \multirow[t]{2}{*}{ Host } & \multirow[t]{2}{*}{ Locality } & \multicolumn{2}{|l|}{ GenBank ID ${ }^{\mathrm{b}}$ [Reference] } \\
\hline & & & 285 & ITS2 \\
\hline Crepidostomum sp. 2 & Diura bicaudata & Norway: Lake Takvatn & KY513152 [18] & \\
\hline Crepidostomum affine & Hiodon tergisus & USA: Pearl River, Mississippi & KF250358 [4] & \\
\hline Crepidostomum affine & $\begin{array}{l}\text { Aplodinotus } \\
\text { grunniens }\end{array}$ & USA: Pearl River, Mississippi & & KF356363 [4] \\
\hline $\begin{array}{l}\text { Acrolichanus (= Crepidostomum) } \\
\text { auriculatum }\end{array}$ & Acipenser schrenkii & Russian Far East & FR821371 [30] & \\
\hline Crepidostomum auritum & $\begin{array}{l}\text { Aplodinotus } \\
\text { grunniens }\end{array}$ & USA: Pearl River, Mississippi & KF250357 [4] & KF356373 [4] \\
\hline Crepidostomum cornutum & Lepomis gulosus & USA: Pascagoula River, Mississippi & EF032695 [62] & KF356374 [4] \\
\hline Crepidostomum farionis $^{\mathrm{a}}$ & P. casertanum & Norway: Lake Takvatn & KY513139 [18] & \\
\hline Crepidostomum farionis & Pisidium sp. & Norway: Lake Takvatn & KY513136 [18] & \\
\hline Crepidostomum farionis & Oncorhynchus masou & Russian Far East & FR821399, FR821402 [30] & \\
\hline Crepidostomum illinoiense & Hiodon alosoides & USA: Red Lake River,Minnesota & KF356372 [4] & KF356364 [4] \\
\hline Crepidostomum metoecus & $\begin{array}{l}\text { Salvelinus } \\
\text { leucomaensis }\end{array}$ & Russian Far East & FR821405, FR821406 [30] & \\
\hline $\begin{array}{l}\text { Crepidostomum metoecus } \\
\text { (= Crepidostomum nemachilus) }\end{array}$ & Barbatula toni & Russian Far East & FR821408, FR821409 [30] & \\
\hline Crepidostomum metoecus & S. trutta & Norway: Lake Takvatn & KY513148 [18] & \\
\hline Crepidostomum metoecus & P. casertanum & Norway: Lake Takvatn & KY513140 [18] & \\
\hline Crepidostomum metoecus & Gammarus lacustris & Norway: Lake Takvatn & KY513141 [18] & \\
\hline Crepidostomum oshmarini & B. barbatula & $\begin{array}{l}\text { Russia: River Il'd, upper Volga } \\
\text { River basin }\end{array}$ & MH159990, MH159992 & MH143094, MH143095 \\
\hline Crepidostomum oshmarini & Cottus gobio & $\begin{array}{l}\text { Russia: River Il'd, upper Volga } \\
\text { River basin }\end{array}$ & MH159989, MH159991 & MH143090, MH143091 \\
\hline Crepidostomum oshmarini ${ }^{\mathrm{a}}$ & P. casertanum & Lithuania: River Nedzingè & MH159993, MH159994 & MH143092, MH143093 \\
\hline Creptotrema funduli & Fundulus notatus & $\begin{array}{l}\text { USA: Mississippi, Biloxi River, } \\
\text { Harrison County }\end{array}$ & JQ425256 [66] & \\
\hline $\begin{array}{l}\text { Creptotrematina } \\
\text { aguirrepequenoi }\end{array}$ & A. aeneus & $\begin{array}{l}\text { Costa Rica: Rio Tempisquito, } \\
\text { Guanacaste }\end{array}$ & HQ833708 [64] & \\
\hline Phyllodistomum folium & $\begin{array}{l}\text { Gymnocephalus } \\
\text { cernuus }\end{array}$ & Lithuania: Curonian Lagoon & KX957729 [46] & KY307885 [46] \\
\hline Phyllodistomum angulatum & Sander lucioperca & $\begin{array}{l}\text { Russia: Rybinsk water reservoir } \\
\text { on the Volga river }\end{array}$ & KX957735 [46] & KJ740511 [46] \\
\hline Phyllodistomum macrocotyle & $\begin{array}{l}\text { Dreissena } \\
\text { polymorpha }\end{array}$ & Belarus: Lake Lepelskoe & AY288828 [67] & AY288831 [67] \\
\hline
\end{tabular}

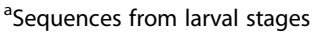

${ }^{\text {b }}$ Sequences generated in the present study are indicated in bold

Representative DNA sequences: ITS2 rDNA (MH143090-MH143095); 28S rDNA (MH159989-MH 159994) (see also Table 1).

\section{Description}

[Based on 25 ovigerous worms; Fig. 1, Table 2.] Body elongate-oval, spindle-shaped, only slightly dorsoventrally flattened, with bluntly rounded extremities, 13321872 (1561) long, with maximum width at level of ventral sucker, 225-396 (284) (Fig. 1a, b). Body width to body length ratio 1:4.4-8.2 (5.8); forebody 270-369
(320) long; hindbody 909-1458 (1229) long, forebody to hindbody length ratio 1:3-4.5 (1:3.9). Tegument smooth. Eye-spot pigment present in all specimens, usually solid, rarely dispersed. Oral sucker ventro-terminal, 136$222 \times 143-210(180 \times 168)$, provided with 6 muscular lobes arranged in ventro-lateral, dorso-median and dorso-lateral pairs; lobes approximately equal in size and well-separated at their bases. Pre-oral lobe very short, 22-44 (29). Ventral sucker round, scyphoid, semi-embedded, almost equal in size to oral sucker, $163-234 \times 156-288(191 \times 197)$; sucker width ratio 


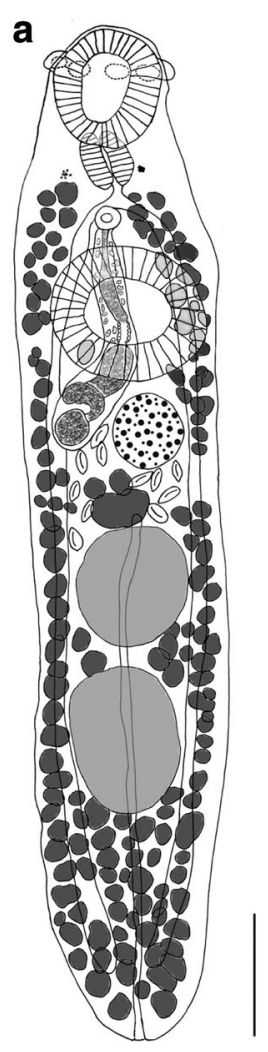

b

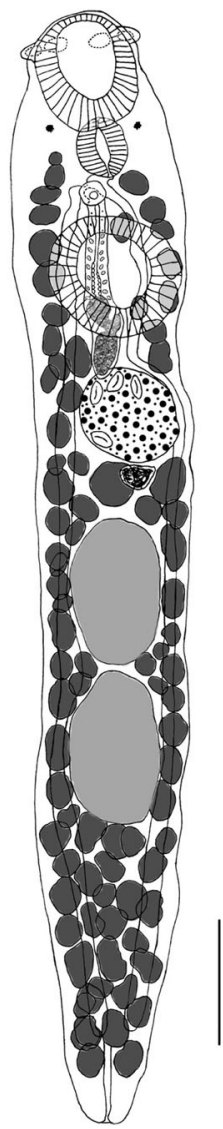

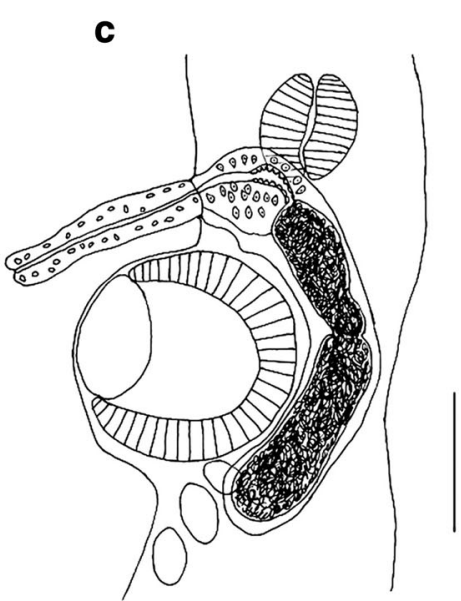

Fig. 1 Crepidostomum oschmarini. a Whole-mount ventral view, ex Barbatula barbatula. b Whole-mount ventral view, ex Cottus gobio. c Terminal genitalia. Scale-bars: a, b, $200 \mu \mathrm{m} ; \mathbf{c}, 100 \mu \mathrm{m}$

1-1.6 (1.3). Prepharynx short; pharynx muscular, elongate-oval, $55-101 \times 68-92(77 \times 76)$; oesophagus short, 15-44 (26); intestinal bifurcation immediately posterior to pharynx, at approximately mid-way between suckers; caeca long, terminating blindly near posterior extremity of body.

Testes 2, oval or globular, tandem, entire, contiguous or slightly separated; near middle of hindbody. Anterior testis 158-246 × 121-209 $(210 \times 164)$, smaller than posterior testis, latter $176-330 \times 132-220(233 \times 171)$. Cirrus-sac elongate, well developed, $242-450 \times 48-82$ $(327 \times 66)$, with anterior end curved ventrally posterior to ventral sucker (Fig. 1c), extends posteriorly from level of intestinal bifurcation to ovarian region (up to posterior margin of ovary); contains coiled seminal vesicle, pars prostatica and ejaculatory duct. Seminal vesicle elongated, variable in size. Pars prostatica rectilinear, near middle of cirrus-sac; prostatic cells sparse, surround pars prostatica and extend throughout anterior half of cirrus-sac. Cirrus tubular, unarmed, 183-198 in length $(n=2)$. Genital atrium absent. Common genital pore median, between pharynx and ventral sucker, typically at level of intestinal bifurcation.
Ovary subspherical, entire, usually about equidistant between ventral sucker and anterior testis, dextrally or sinistrally submedian or in some specimens median, 92 $176 \times 99-163(135 \times 126)$. Proximal female genitalia not clearly observed. Seminal receptacle discerned in some specimens, $46-82 \times 44-99(57 \times 66)$, rounded or somewhat transversely-elongate, immediately posterior to ovary. Uterus short, coiled between anterior testis and ventral sucker, overlapping ovary ventrally, only rarely extending slightly into testicular region; runs ventral to male duct; opens through common genital pore ventrally to male duct. Eggs not numerous, 4-26 (10 on average), operculate, thin-shelled, elongate-oval, 33-70 × 26-37 (59 × 33).

Vitellarium follicular, follicles in 2 lateral fields from level of posterior margin of pharynx to almost posterior extremity of body; fields sparsely confluent dorsally and ventrally in anterior caecal field, confluent dorsally and ventrally in post-testicular region, slightly overlapping testes, but not encroaching laterally between testes; no follicles present dorsal to ovary. Vitelline reservoir large, $55-92 \times 57-110(71 \times 82)$, between ovary and anterior testis. Excretory vesicle tubular, elongate, I-shaped, 
Table 2 Measurements (in $\mu$ m) of Crepidostomum oschmarini from Barbatula barbatula $(n=15)$ and Cottus gobio $(n=10)$

\begin{tabular}{|c|c|c|c|c|}
\hline \multirow{2}{*}{$\begin{array}{l}\text { Host species } \\
\text { Variable }\end{array}$} & \multicolumn{2}{|c|}{ Barbatula barbatula } & \multicolumn{2}{|l|}{ Cottus gobio } \\
\hline & Range & Mean & Range & Mean \\
\hline Body length & $1332-1800$ & 1432 & $1476-1872$ & 1652 \\
\hline Maximum body width & 264-396 & 309 & $225-300$ & 263 \\
\hline Body width/length & $4.4-8.2$ & 5.1 & $4.9-8$ & 6.4 \\
\hline Forebody length & $270-342$ & 305 & $297-369$ & 334 \\
\hline Hindbody length & $909-1300$ & 1150 & $1170-1458$ & 1307 \\
\hline Hindbody/forebody length & $3-4.3$ & 3.8 & $3.6-4.5$ & 4 \\
\hline Pre-oral lobe length & $22-66$ & 44 & $22-44$ & 29 \\
\hline Oral sucker length & $136-189$ & 156 & $180-222$ & 201 \\
\hline Oral sucker width & $143-185$ & 154 & $144-210$ & 180 \\
\hline Muscular lobes length & $40-46$ & 43 & $46-68$ & 57 \\
\hline Muscular lobes width & $22-24$ & 23 & $22-35$ & 29 \\
\hline Pharynx length & $55-90$ & 71 & $68-101$ & 83 \\
\hline Pharynx width & $68-77$ & 73 & $68-92$ & 79 \\
\hline Oesophagus length & $26-44$ & 33 & $15-26$ & 20 \\
\hline Ventral sucker length & $163-222$ & 184 & $165-234$ & 197 \\
\hline Ventral sucker width & $156-288$ & 203 & $165-228$ & 192 \\
\hline Ovary length & $92-136$ & 113 & $128-176$ & 155 \\
\hline Ovary width & 99-139 & 112 & $121-163$ & 138 \\
\hline Seminal receptacle length & $55-59$ & 57 & $46-82$ & 57 \\
\hline Seminal receptacle width & $44-73$ & 59 & $55-99$ & 74 \\
\hline Vitelline reservoir length & 59-92 & 72 & $55-82$ & 70 \\
\hline Vitelline reservoir width & 79-99 & 87 & $57-110$ & 76 \\
\hline Anterior testis length & $158-233$ & 183 & $216-246$ & 235 \\
\hline Anterior testis width & $121-209$ & 156 & 130-198 & 170 \\
\hline Posterior testis length & $176-242$ & 200 & $222-330$ & 262 \\
\hline Posterior testis width & $132-220$ & 163 & $132-210$ & 178 \\
\hline Seminal vesicle length & $66-209$ & 146 & $66-143$ & 109 \\
\hline Seminal vesicle width & $44-88$ & 70 & $30-66$ & 47 \\
\hline Cirrus-sac length & $244-420$ & 332 & $242-450$ & 322 \\
\hline Cirrus-sac width & $48-82$ & 71 & $48-77$ & 60 \\
\hline Egg length & $48-68$ & 58 & $33-70$ & 60 \\
\hline Egg width & $26-35$ & 32 & $29-37$ & 34 \\
\hline Ventral sucker/oral sucker width & $1-1.6$ & 1.3 & $0.9-1.4$ & 1.1 \\
\hline Oral sucker/pharynx length & $1.9-2.6$ & 2.2 & $2.2-2.8$ & 2.5 \\
\hline No. of eggs & $4-26$ & 11 & $4-14$ & 9 \\
\hline
\end{tabular}

reaches anterior margin of anterior testis. Excretory pore subterminal.

\section{Remarks}

The specimens of C. oschmarini from B. barbatula are similar to those from $C$. gobio except in some morphological details that we do not consider to be of taxonomic importance. The worms from C. gobio have larger values for body length, body width to length ratio, oral sucker, muscular lobes on the oral sucker, pharynx, ovary, testes and eggs than the worms from B. barbatula. Crepidostomum oschmarini from $B$. barbatula also differs from the worms from $C$. gobio in the more rounded shape of testes.

Four species of the genus Crepidostomum (C. metoecus, C. farionis, C. latum, C. wikgreni) have been recorded from freshwater fishes in Europe. Here we do not consider C. auriculatum as this species is a specific parasite of sturgeons $[1,5]$ and appears to be much closer to Bunodera 
spp. than to its congeners in $28 \mathrm{~S}$ rDNA based molecular phylogenies $([18,30]$, present study). The following species can be readily distinguished from C. oschmarini.

Crepidostomum metoecus differs in the larger size of the body and cirrus-sac, smaller hindbody to forebody length ratio of 1:2.2, longer oesophagus, larger number of eggs in uterus, 8-79 (mean 30) [1], and in the position of the genital pore (posterior to intestinal bifurcation) [1,31]. The ovigerous worms from central Europe lack eye-spot pigment [31-34], the worms from Britain, Japan and USA have small scattered eye-spot pigment $[1,8,35]$.

Crepidostomum farionis differs in the much larger size of the body, suckers, pharynx and eggs, and in having a much longer oesophagus and cirrus-sac, smaller forebody to hindbody length ratio of $1: 2.5$, as well as in the possession of separate genital pores which open anterior to the intestinal bifurcation $[1,36]$. The ovigerous worms lack eye-spot pigment in the forebody [33, 34, 37-39], or eye-spot pigment is small and scattered $[1,8,35,40]$. The uterus in C. farionis often extends into the testicular region (up to middle of anterior testes), the excretory vesicle is Y-shaped and eggs are numerous, up to 230 [34, 37, 38].

Crepidostomum latum Pigulewsky, 1931 has a wider body with a much shorter forebody and much larger size of eggs [41]. It differs from C. oschmarini by its shorter S-shaped cirrus-sac not reaching the posterior margin of the ventral sucker; shorter lateral fields of the vitellarium reaching anterior to the posterior margin of the ventral sucker; uterus extending into testicular region and lateral fields around the ventral sucker; testes which are almost equal in size.

Crepidostomum wikgreni is closest to C. oschmarini from which can be distinguished by its larger size of the body, pharynx, ventral sucker, ovary, testes, eggs, and in having a much longer oesophagus and shorter cirrus-sac and a specific microhabitat in the host (gall-bladder). Additionally, the ovigerous worms lack eye-spot pigment, the common genital pore is pre-bifurcal and the number of eggs in uterus is larger than in C. oschmarini ( $<50$ [42]).

The main morphological difference distinguishing $C$ oschmarini from the species listed above is the eye-spot pigment in the forebody; this character was clearly present in all specimens. Furthermore, the very short oesophagus differentiates $C$. oschmarini from its congeners parasitizing salmonid fish hosts.

\section{Tegumental topography of Crepidostomum oschmarini}

Under SEM, the ventral and dorsal tegumental surface of C. oschmarini is unarmed and possesses transverse ridges (Figs. 2a and 3c, f). The presence of cobblestone-like protrusions on the body surface was apparent at a higher magnification (Fig. 3g). The anterior extremity of the body bears a ventro-terminal oral sucker provided with six protruding, muscular lobes (Fig. 2a, c, d). These lobes are arranged in three symmetrical pairs, ventro-lateral, dorso-lateral and dorso-median (Fig. 2c, d). The dorsomedian and dorso-lateral lobes are approximately equal in size, whereas the ventro-lateral lobes are slightly wider. As they are continuous with the margin of the oral sucker, the anterior region of the ventro-lateral lobes form the anterior part of the oral sucker rim (Fig. 2b-c). There are numerous sensory endings in the form of so-called "papillae and minute sensory receptors" $[1,7,12]$ on the oral sucker rim, around the oral sucker rim and along the interlobular field dorsally to the oral sucker (Fig. 2b-d). Five papillate sensory endings (c.6.5 $\mu \mathrm{m}$ in diameter) occur evenly spaced, about $40 \mu \mathrm{m}$ apart from each other, and consistently associated with the posterior portion of the oral sucker rim (Fig. 2b, c). Underneath the ventro-lateral papilla of the oral sucker, groups of 8 papillae are visible on either side of the rim (Fig. 2c, f). In all of the specimens studied, there is a constant pattern of 3 pairs of symmetrical papillae, which vary in size, located at the middle of the anterior rim of the oral sucker (Fig. 2b-d, e). On each side of this symmetrical arrangement, the posteriormost papilla $(c .7 \mu \mathrm{m}$ in diameter) is situated about $5 \mu \mathrm{m}$ from the middle papilla (c.4.5 $\mu \mathrm{m}$ in diameter), which, in turn, is situated about $4 \mu \mathrm{m}$ from anteriormost papilla $(c .3 .5 \mu \mathrm{m}$ in diameter) (Fig. 2e). The distance between posteriormost papillae on each side is $21 \mu \mathrm{m}$, between the middle papillae $32 \mu \mathrm{m}$ and between anteriormost papillae $17 \mu \mathrm{m}$ (Fig. 2e). An additional papilla (c.4.5 $\mu \mathrm{m}$ in diameter) is situated on the surface of each vento-lateral lobe (Fig. 2d, g). Two kinds of sensory endings, papillate and non-papillate, are scattered irregularly on the interlobular field of the body (Fig. 2c, d). A group of non-papillate sensory endings occurs close to the 3 pairs of symmetrical papillae (Fig. 2d). Variability exists in the numbers and arrangement of additional papillae in this region (Fig. 2c, d). Not far from the margins of the dorso-lateral lobes, groups of 3-5 papillae are present (Fig. 2d, h); furthermore, between the ventro-lateral and dorso-lateral lobes, 6 papillae and 3-5 non-papillate sensory endings are apparent (Fig. 2d). Non-papillate sensory endings are also present close to the margins of the dorso-median lobes. All of the sensory endings (papillate and non-papillate) on the anterior body surface are ciliate receptors (Fig. 2i, j).

The ventral sucker is protruded ventrally. Its rim exhibits surface corrugations arranged radially (Fig. 3d) and bears six large dome-shaped papillae $(c .5 .5 \mu \mathrm{m}$ in diameter) regularly distributed around the rim (Fig. 3c-e).

The common genital pore is median between the two suckers (Fig. 5a, c); no tegumental papillae were observed around the genital pore (Fig. 3b-d). The tegument around the genital pore may form a weak elevation at the base of the everted cirrus (Fig. 3b, c). The surface of the cirrus is smooth (Fig. 3d). Everted cirrus was observed, measuring between $65-160 \mu \mathrm{m}$ in length at different degrees of evagination (Fig. 3a, c, d). 

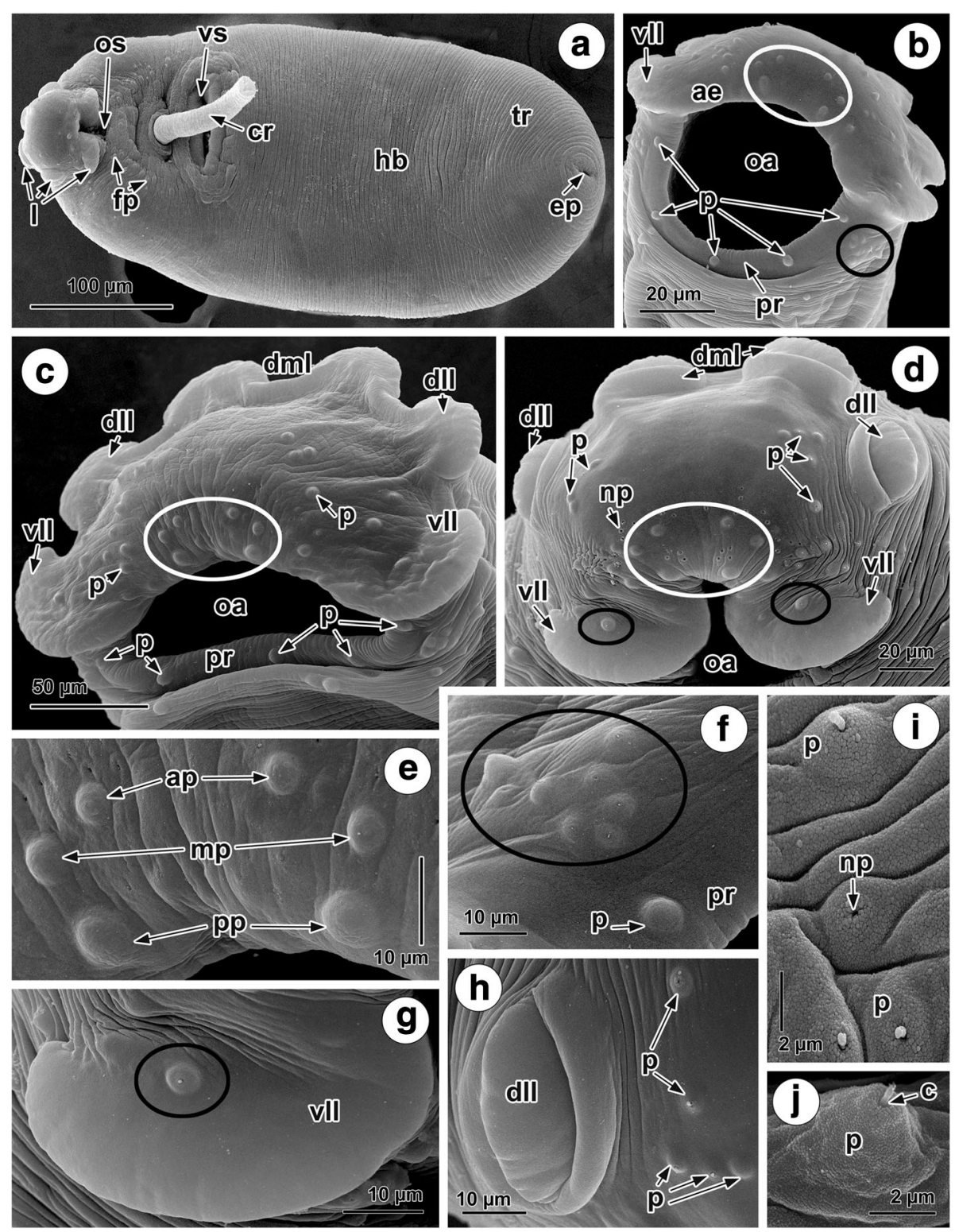

Fig. 2 SEM micrographs of the surface topography of the anterior region of the body of Crepidostomum oschmarini. a Ventral view of mature worm. $\mathbf{b}$ The constant pattern of 5 papillae on the posterior rim of the oral sucker, 3 symmetrical pairs of papillae in the middle of the anterior rim (white circle) and a group of 8 papillae underneath the sucker rim (black circle). c 3 paired symmetrical papillae (white circle) and the distribution of irregular papillae on the anterior rim. $\mathbf{d}$ Interlobular field with marked (white circle) of 6 symmetrical papillae, irregular papillate and non-papillate sensory endings and single papilla on each ventro-lateral lobe (black circles). e Regular pattern of different sizes of the posteriormost, middle and anteriormost pairs of 6 symmetrical papillae on anterior rim. $\mathbf{f}$ Regular arrangement of 8 papillae ventro-lateral to the posterior sucker rim (black circle). $\mathbf{g}$ Single papilla (black circle) on the surface of a ventro-lateral lobe. $\mathbf{h}$ Papillae close to the base of a dorso-lateral lobe. $\mathbf{i}$ Ciliated papillate and nonpapillate sensory endings on interlobular field. $\mathbf{j}$ Ciliated papilla. Abbreviations: ap, anteriormost papilla; c, cilium; cr, cirrus; dll, dorso-lateral lobe; dml, dorso-median lobe; fp, forebody papillae; hb, hindbody; ep, excretory pore; l, lobe; mp, middle papilla; np, non-papillate sensory ending; oa, oral aperture; os, oral sucker; p, ciliated papilla; pp, posteriormost papilla; pr, posterior rim of oral sucker; tr, transverse tegumental ridges; vll, ventro-lateral lobe; vs, ventral sucker

Papillae are present on the forebody surface but are more abundant ventrally; they exhibit a tendency for bilateral symmetry (Fig. 3a, b). A gathering of ciliated and dome-shaped papillate sensory endings, arranged in two longitudinal, symmetrical rows, occurs on the ventral surface between the oral and ventral suckers (Fig. 3b). There are also a few papillae present in ventro-lateral and dorso-lateral areas of the forebody (Fig. 3a). The hindbody lacks papillae (Figs. 2a, 3f). Situated at the posterior extremity of the body is the excretory pore (Fig. 3f). 

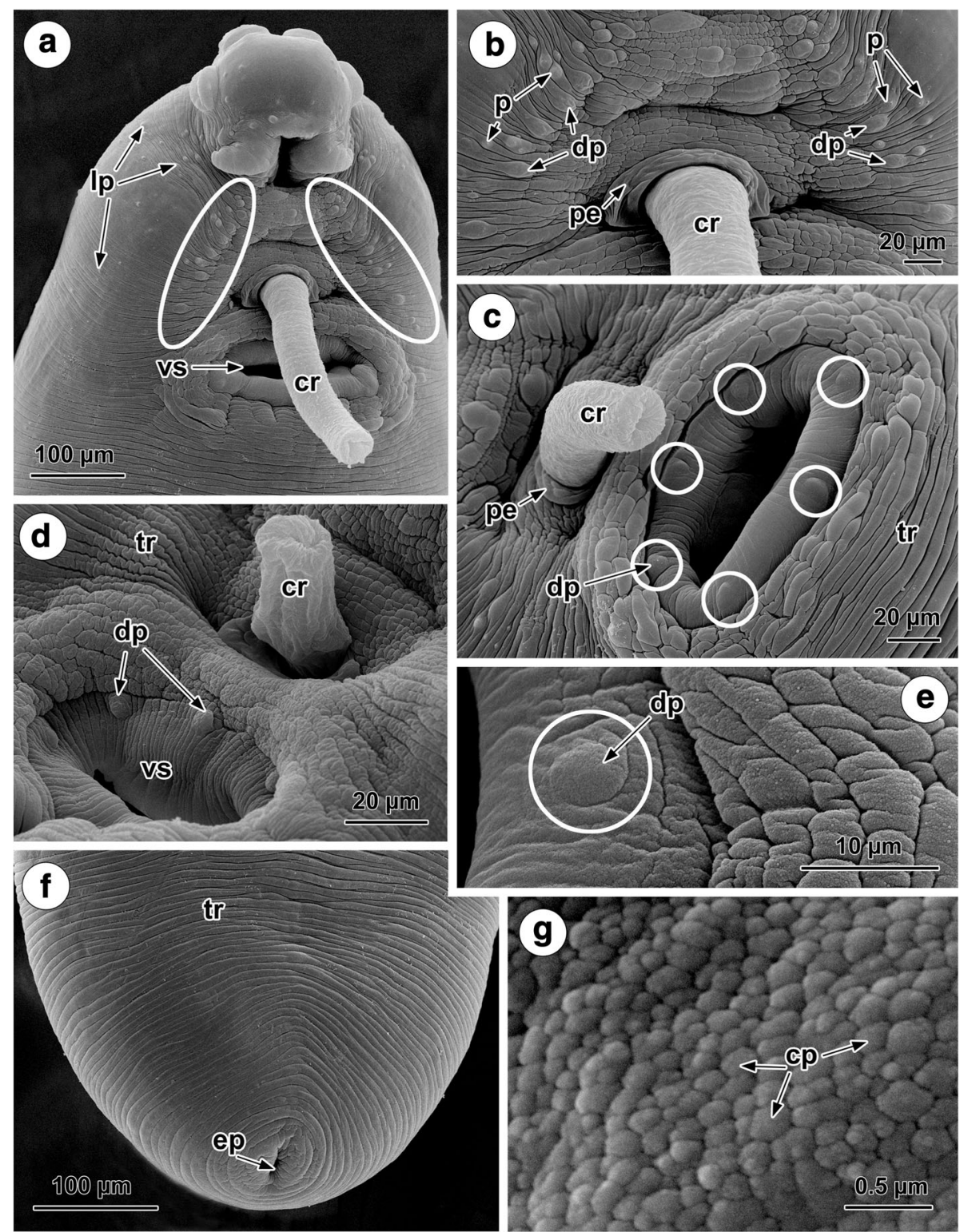

Fig. 3 SEM micrographs of the surface topography of the forebody and hindbody of Crepidostomum oschmarini. a Two symmetrical longitudinal fields of papillae (white circles), the protruded cirrus and the ventral sucker on the forebody. $\mathbf{b}$ Ciliated and dome-shaped sensory endings in the two longitudinal fields of papillae. c Ventral sucker with 6 dome-shaped papillae on its rim (white circles). $\mathbf{d}$ Radially arranged surface corrugations on the rim of the ventral sucker and the dome-shaped papillae. e Dome-shaped papilla (white circle) on the ventral sucker rim. $\mathbf{f}$ Posterior extremity of the body with the terminal excretory pore. $\mathbf{g}$ Cobblestone-like protrusions of the body surface. Abbreviations: $\mathrm{cp}$, cobblestone-like protrusion; $\mathrm{cr}$, cirrus; dp, dome-shaped papilla; ep, excretory pore; Ip, lateral papilla; p, ciliated papilla; pe, elevation around genital pore; tr, transverse tegumental ridges; vs, ventral sucker

\section{Molecular differentiation and phylogenetic analysis}

Two genetically different Crepidostomum cercariae were collected from $P$. casertanum in Lake Sagelvvatn in Norway, corresponding to Crepidostomum sp. 1 and Crepidostomum sp. 2 sensu Soldánová et al. (2017) [18] recorded in Lake Takvatn, Norway. One of these isolates was genetically identical to the metacercariae of Crepidostomum sp. 2 ex mayfly Siphlonurus lacustris and to adult ex Salmo trutta [18]. In Crimea, Crepidostomum sp. cercariae were found in $P$. casertanum collected in the River Burulcha. This cercaria has been described previously as the larva of $C$. metoecus [16], although the divergence between these two species ranged between $0.6-0.7 \%$ (7-8 bp) in the alignment of the $28 S$ gene. The divergence between the Crimean Crepidostomum sp. and the sub-Artic Crepidostomum sp. 2 can be regarded as intraspecific, with $2-3 \mathrm{bp}(0.2-0.3 \%)$ difference in the $28 S$ and only 1 bp $(0.16 \%)$ in the $5.8 S$-ITS2. 
Adult Crepidostomum specimens obtained from $S$. trutta in Lake Sagelvvatn were genetically identical to samples of cercariae from P. casertanum and Pisidium sp. collected in this lake and from Sphaerium nitidum in Lake Kykkelvatn. The sequences of the $28 S$ rRNA gene obtained from all of these samples were identical to Crepidostomum sp. 1 samples collected from Sphaerium sp. and S. lacustris in Lake Takvatn [18]. Intraspecific variation was detected in Lake Sagelvvatn, but only a single nucleotide in the ITS2 was different in one specimen from S. trutta and in one isolate from Pisidium sp.; also this site was heterozygotic in one sample from $P$. casertanum, obviously as a result of hybridization of two genetically different lineages.

The newly generated rDNA sequences of $C$. oschmarini sampled from B. barbatula and C. gobio in Russia, and from $P$. casertanum in Lithuania were identical. The $28 S$ sequences were aligned with those of closely related species in an alignment of $1150 \mathrm{bp}$. The divergence between C. oschmarini and C. metoecus was 8 and 9 bp (0.7-0.8\%), the divergence between C. oschmarini and the sub-Arctic Crepidostomum sp. 2 was 11 and 12 bp (0.96-1\%). However, C. oschmarini was less different from the Crimean Crepidostomum sp. 2 (9 bp, 0.8\%).

Some specimens of $P$. casertanum, collected in the River Burulcha and in Lake Takvatn, Norway, as well as Pisidium sp. from Lake Nordersjoen, were infected with Allocreadium neotenicum. All samples were genetically identical. In a $28 S$ alignment of $1150 \mathrm{bp}$, no nucleotide differences were detected between our samples and $A$. neotenicum collected from the dytiscid beetles Oreodytes sanmarkii and Hydroporus rufifrons in the sub-Arctic Lake Takvatn and the Lake District in Cumbria, UK, respectively $[18,43]$.

New rDNA sequences were obtained for $A$. isoporum, collected from B. barbatula in the upper Volga River basin, Russia. These sequences were identical to rDNA of A. isoporum collected from Alburnus alburnus in Lake Oster, Karelia, Russia [44], with one difference in a single nucleotide of the ITS2.

New rDNA sequences were obtained for B. luciopercae, collected from Perca fluviatilis in the Curonian Lagoon, Lithuania. The divergence between sequences from this specimen and sequences of $B$. luciopercae specimens from a previous study [44] was 2 and $3 \mathrm{bp}$ in a $28 S$ alignment of $1067 \mathrm{bp}$ and only $1 \mathrm{bp}$ in the ITS2 alignment of $394 \mathrm{bp}$.

The newly obtained sequences and relevant allocreadiid sequences of ITS2 rDNA and partial $28 S$ rDNA from the GenBank database were used for phylogenetic analysis. Alignment of the ITS2 and partial $28 S$ data yielded 394 and 1050 characters for analysis, respectively.

Phylogenetic analyses of the ITS2 and $28 S$ datasets produced several strongly supported clades and some weakly or not supported clades in both phylogenetic trees (Figs. 4, 5). Adult C. oschmarini from two fish species, B. barbatula and C. gobio, and allocreadiid cercariae from the sphaeriid bivalve P. casertanum, formed a strongly supported monophyletic subclade (Figs. 4, 5). Sub-Arctic Crepidostomum sp. 2 together with Crimean Crepidostomum sp. formed the other subclade. These two subclades nested in to a well-supported monophyletic clade; in the $28 S$ tree C. metoecus is included into this clade. Crepidostomum sp. 1 formed the other monophyletic clade (Fig. 5); in the $28 S$ tree, together with $C$. farionis (Fig. 4). This clade was nested as sister to the clade formed by C. oschmarini + Crepidostomum sp. $2+$ C. metoecus but the relationship was not supported (Fig. 4). Unfortunately, ITS2 data for C. metoecus and for C. farionis are not yet available. Nearctic Crepidostomum species nested into a separate monophyletic clade together with species from the allocreadiid genera Auriculostoma and Creptotrematina in the two trees and, additionally, with Creptotrema and Paracreptotrematoides in the $28 S$ tree. Species of Allocreadium, as well as species of Bunodera, nested into two separate monophyletic clades (Figs. 4, 5). However, the relationships among all these clades showed some differences in the different trees. In the $28 \mathrm{~S}$ rDNA tree, all these clades and the branch of Acrolichanus auriculatum were united into one strongly supported main clade, but did not form supported higher-level clades inside the main clade. The main difference between the ITS2 and $28 \mathrm{~S}$ rDNA trees was in the relationships of Crepidostomum species. In the ITS2 tree, the strongly supported clade of Nearctic Crepidostomum spp. and the clade of $C$. oschmarini-Crepidostomum sp. 2 nested into a well-supported higher-level clade (Fig. 5), while in the $28 S$ tree (Fig. 4), the clade of Nearctic Crepidostomum spp. was not strongly supported and its relationships with other clades of Crepidostomum was not supported.

\section{Discussion}

The results of this study shed new light on the diversity of trematodes of the genus Crepidostomum in Europe. The existing genetic data was based on analysis of partial sequences of the $28 \mathrm{~S}$ rRNA gene of Crepidostomum species that use salmonid fishes as final hosts [18]. Crepidostomum oschmarini was found from two sympatric but phylogenetically distant fish host species, $B$. barbatula (Cypriniformes) and C. gobio (Scorpaeniformes). Although host switching is probably easier among related host species [45], host switches between unrelated hosts can also take place [46-48]. While B. barbatula and $C$. gobio are phylogenetically distant, their feeding habitats and food preferences are similar. Predominant preys are small benthic arthropods (insect larvae, i.e. ephemeropterans, plecopterans, trichopterans and crustaceans $[49$, 


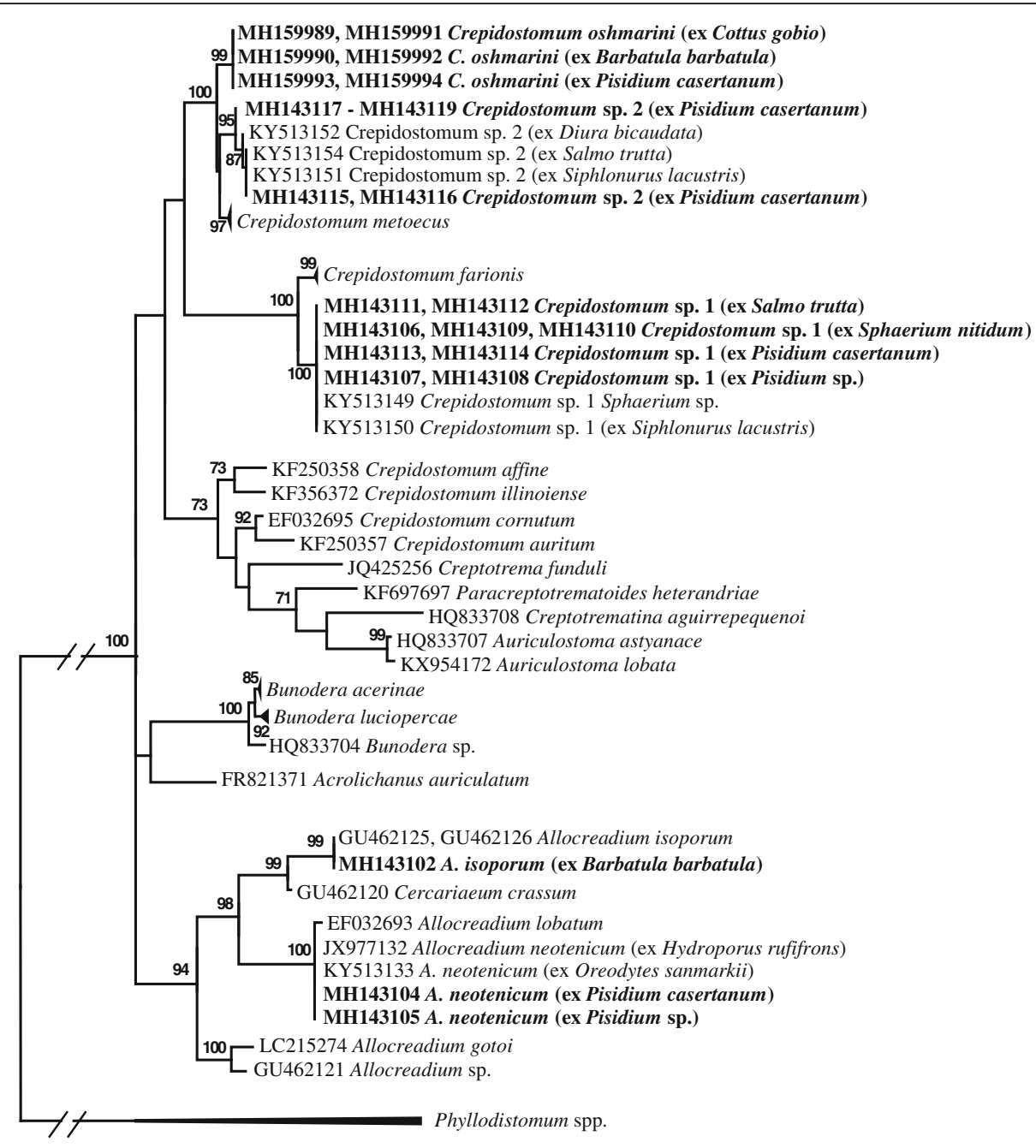

Fig 4 Phylogenetic tree based on Maximum Likelihood analysis of partial sequences of the 285 nuclear rRNA gene. Bootstrap support values lower than $70 \%$ are not shown. GenBank accession numbers of sequences in collapsed clades are provided in Table 1. The species sequenced in this study are indicated in bold

50]). It is likely that a feeding overlap produced by food items that are involved in the life-cycle of the parasite, resulted in the infection of both fish with the same Crepidostomum species.

Comparative sequence analysis in this study confirmed the link between the redial and cercarial isolates ex $P$. casertanum from the River Nedzinge, Lithuania, and the adult stages of $C$. oschmarini parasitizing B. barbatula and C. gobio from the River Il'd, Russia. No intraspecific variation was detected between these isolates, despite the considerable geographical distance $(\sim 1000 \mathrm{~km})$ between the Lithuanian and Russian populations.

The level of differences found between the partial $28 \mathrm{~S}$ rDNA sequences of C. oschmarini and C. metoecus (0.6$0.7 \%$ ) clearly demonstrates that these two forms are different species. The observed level of differences is similar to the levels of interspecific variability reported for allocreadiid digeneans [4, 18, 30, 44]. It is notable that occasionally relatively low interspecific genetic divergence can be discovered in related allocreadiid species; for instance, only $0.29 \%$ divergence was found between Auriculostoma lobata Hernández-Mena, Lynggaard, Mendoza-Garfias \& Pérez-Ponce de León, 2016 and its sister species $A$. astyanace Scholz, AguirreMacedo \& Choudhury, 2004 (Allocreadiidae) [51]. Despite the conservative nature of the 285 rDNA gene region, it segregates well-supported subclades of $C$. metoecus, Crepidostomum sp. 2 and C. oschmarini, within a single clade (Fig. 4).

Recently, the existence of cryptic species was uncovered among Crepidostomum spp. infecting salmonid fishes and different first and second intermediate hosts in the sub-Arctic Lake Takvatn [18]. Hence, molecular results evidenced that species diversity in 


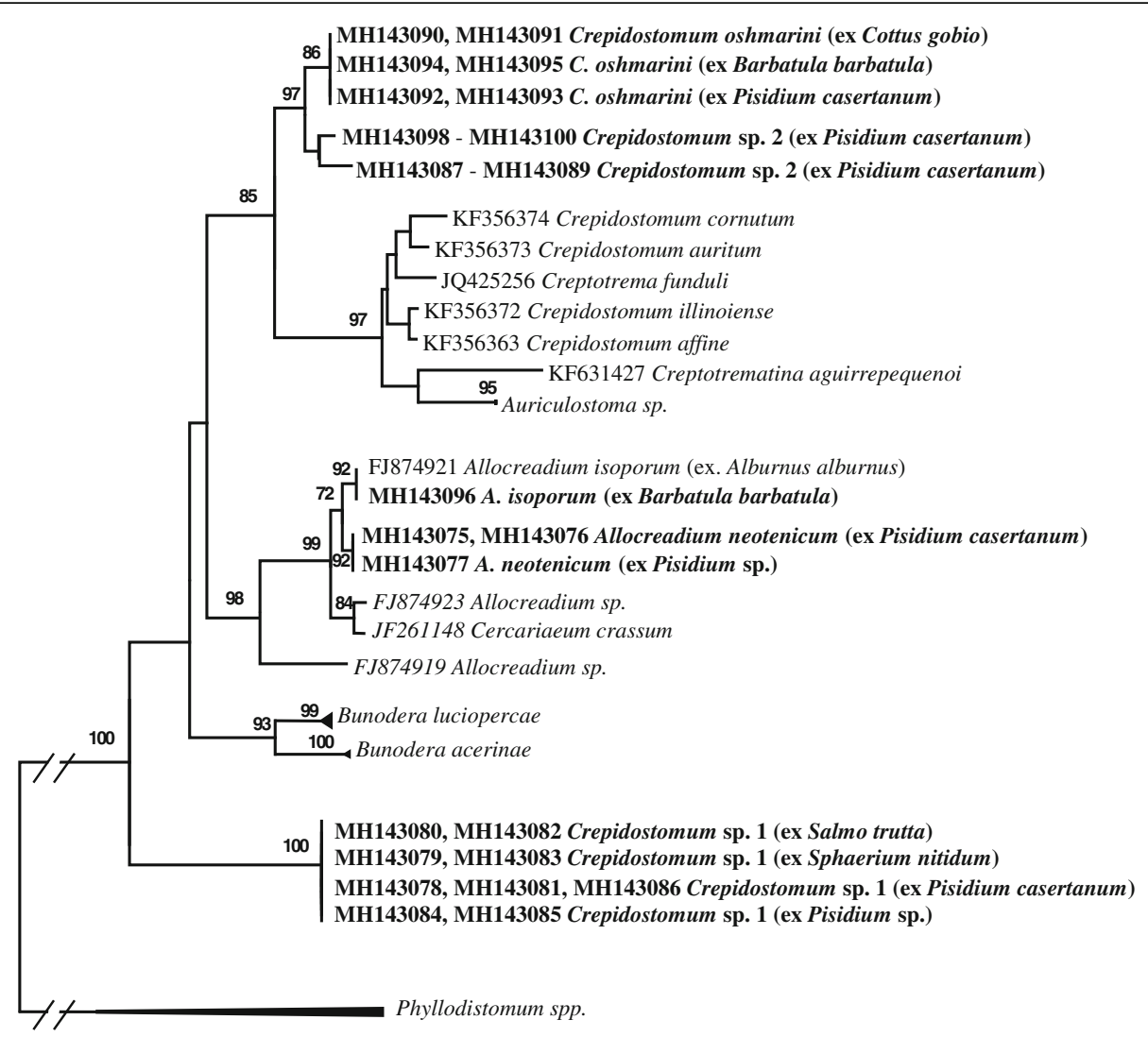

Fig. 5 Phylogenetic tree based on maximum likelihood analysis of the ITS2 nuclear rDNA region. Bootstrap support values lower than $70 \%$ are not shown. GenBank accession numbers of sequences in collapsed clades are provided in Table 1. The species sequenced in this study are indicated in bold

Crepidostomum is underestimated. Molecular data obtained from analysis of $28 \mathrm{~S}$ rDNA partial sequences disclosed two pairs of genetically closely related species, i.e. C. farionis - Crepidostomum sp. 1, and C. metoecus-Crepidostomum sp. 2. Considering that there are only five nominal European Crepidostomum species included into the Fauna Europaea database [52], i.e. C. auriculatum Wedl, 1858, C. farionis, C. latum, C. metoecus and C. wikgreni Gibson \& Valtonen, 1988, the finding was surprising and shows that diversity in this genus and in this otherwise depauperate freshwater ecosystem is higher than was presumed. Crepidostomum farionis and $C$. metoecus were known as the only two species of this genus parasitizing salmonids in Europe [5, 34]. Crepidostomum wikgreni described from the gall-bladder and intestine of the whitefish Coregonus acronicus (Salmonidae) in Lake Yli-Kitka, northeast Finland, has never been recorded elsewhere and is regarded as an endemic form [42]. No sequence data are available for this species and it could not be included in molecular phylogenies. The gross morphology of $C$. wikgreni appeared very similar to $C$. farionis and it was suggested that $C$. wikgreni has probably evolved from C. farionis after deglaciation and since $c .8400 \mathrm{BP}$ when the waters of the Kitka Lake system were isolated [42]. These two species presumably represent closely related sister taxa.

Crepidostomum nemachilus was originally described from Nemachilus barbatulus toni (Nemacheilidae) on Sakhalin Island in the Russian Far East [53]. The genetic identity of $C$. nemachilus and C. metoecus was revealed in comparative analysis of $28 S$ sequences, but distinctions observed in morphology of the two species were regarded as an argument to refrain from deciding upon synonymy of the two taxa [30]. However, recent morphological reexamination of $C$. nemachilus from the type-host Barbatula toni (Dybowski) (syn. Nemachilus toni) showed that it is consistent with the specimens of $C$. metoecus including those found in B. toni in every essential feature [8]. Thus, both molecular and morphological findings demonstrated that $C$. nemachilus is a synonym of $C$. metoecus.

Acrolichanus auriculatum (syn. Crepidostomum auriculatum), a parasite of sturgeons, comprise a separate branch in the molecular $28 S$ rDNA phylogenetic tree, distantly related to other Crepidostomum spp. [18, 30]. 
Wedl [54] described this species as Distoma auriculatum. Since then, it has undergone many taxonomic revisions (see $[1,55])$. Skwortzoff [56] conducted a comprehensive morphological analysis of the species based on a large amount of material collected from Acipenser ruthenus from the Volga River and Oka River, concluding that they should be assigned to the genus Acrolichanus Ward, 1917. Thus, there have been opposing opinions on the validity of Acrolichanus. Some authors, along with Hopkins [57], are of the opinion that this taxon is insufficiently distinct from Crepidostomum and must be placed within the latter genus. However, molecular data support the opinion of Skryabin \& Koval [55] and Bykhovskaya-Pavlovskaya \& Kulakova [5] that A. auriculatum is distinct enough from samples of the other Palaearctic and Nearctic Crepidostomum spp. to be assigned to another genus. In $28 S$ rDNA based phylogenies $A$. auriculatum appears to be much closer to Bunodera spp. than to Crepidostomum spp.

Crepidostomum latum is a little-known species described by Pigulewsky [41] based on only two specimens from the intestine of the rudd, Scardinius erythrophthalmus (L.) (Cyprinidae), in the River Sozh (in the upper course of the River Dnepr, Ukraine). The species has not been encountered since and its validity is questionable [5].

The $28 S$ rDNA based phylogenetic tree generated here agrees in general topology with recently published estimates of phylogeny for the Allocreadiidae [18, 58]. In these studies, the species of the genera Allocreadium and Bunodera formed two monophyletic clades. The different situation concerns the genus Crepidostomum. In the present analyses C. oschmarini, C. metoecus (syn. C. nemachilus Krotov, 1959) and Crepidostomum sp. 2 represented closely related sister taxa in the $28 \mathrm{~S}$ rDNA-based phylogeny. We refer to this clade as the $C$. metoecus complex. The second clade, including European Crepidostomum isolates was comprised of $C$. farionis and Crepidostomum sp. 1. Our sequences for isolates sampled from Sphaerium nitidum, Pisidium sp., $P$. casertanum and S. trutta from Norway matched the sequences of Crepidostomum sp. 1 of Soldánová et al. [18]. However, a monophyletic origin of the two Crepidostomum clades is not supported in the $28 \mathrm{~S}$ rDNA-based phylogeny. DNA sequences, unconstrained by function, as the internal transcribed spacer 2 (ITS2), usually experience higher rates of genetic change than encoding regions, as the $28 S$. In the ITS2-based phylogeny, the Crepidostomum sp. 1 clade was distant from all other allocreadiid clades, but the C. metoecus complex and Nearctic Crepidostomum clade formed well-supported higher-level clade (Fig. 5). It is interesting that the Nearctic Crepidostomum clade combines some species of the other allocreadiid genera, i.e.
Auriculostoma and Creptotrematina in the ITS2 tree, and even more genera comprise this clade in the $28 \mathrm{~S}$ tree. The results of the phylogenetic analyses led us to a presumption that at least two groups of Crepidostomum species are paraphyletic. There are more cases known when molecular analysis using the $28 \mathrm{~S}$ rDNA gene revealed paraphyly in a group of allocreadiid trematodes, conventionally regarded as a monophyletic assemblage. Hence, recently the genus Paracreptotrema Choudhury, Pérez-Ponce de León, Brooks \& Daverdin, 2006 was shown to be a paraphyletic and two new genera were erected to accommodate the taxonomy with the results of molecular phylogeny [58].

The sequences of isolates of the intramolluscan stages from $P$. casertanum collected in the River Burulcha, Crimea, formed a robustly supported subclade with metacercarial and adult isolates of Crepidostomum sp. 2 sensu Soldánová et al. (2017) [18] from a sub-Arctic lake in Norway. This finding did not match our expectations, as the upper stream of the River Burulcha, Crimea, is the type-locality for the cercarial material used by Stenko [16] for experimental life-cycle studies on $C$. metoecus. Notably, the second intermediate hosts recorded in the study of Stenko [16] were nymphs of the mayfly (Ephemeroptera) and stonefly (Plecoptera). Nymphs of these insects were found infected with metacercariae of Crepidostomum sp. 2 in the molecular study of Soldánová et al. [18]. On the other hand, amphipods Gammarus lacustris were found to be the second intermediate host of $C$. metoecus in Lake Takvatn in Norway [18]. Based on these facts, we can assume that Stenko [16] was dealing with Crepidostomum sp. 2. Adult specimens of Crepidostomum sp. 2 were recorded in brown trout, S. trutta, in the molecular study of Soldánová et al. [18], and Stenko [16] noted that S. trutta fario was naturally infected with "C. metoecus" in the River Burulcha. Speciation patterns of parasites may be directly associated with their hosts, though in the case of parasites with complex life-cycles it is often less clear which host may have the most influence on parasite speciation. The life-cycle peculiarities of two closely related species, $C$. metoecus and Crepidostomum sp. 2, would suggest that the speciation was driven by factors associated with the second intermediate hosts, phylogenetically distant arthropods, while the first intermediate and definitive hosts are shared between these two trematode species. However, a more accurate knowledge of life-cycles is necessary to explain the pattern of cryptic diversity observed in Crepidostomum spp.

The molecular segregation of C. oschmarini and $C$. metoecus prompted us to compare these worms using SEM and to try to identify diagnostic morphological features for the species. The present SEM study of the surface morphology of C. oschmarini revealed both common 
and specific patterns in the number and arrangement of tegumental papillae as compared with other similarly studied species of Crepidostomum [1, 7, 12, 13].

The five large papillae detected on the posterior rim of the oral sucker of C. oschmarini are common to all of the Crepidostomum species examined to date and can be seen in SEM photos of C. metoecus, C. farionis, C. illinoiense Faust, 1918, C. ictaluri (Surber, 1928) and C. cooperi Hopkins, 1931, published by Caira [1], as well as in C. farionis and C. metoecus examined by Moravec [7] and Žd'árská \& Nebesářová [13] and also in C. opeongoensis Caira, 1985 studied by Choudhury \& Nelson [12]. Five characteristic larger papillae are also visible on the posterior rim of the oral sucker in other allocreadiid species, e.g. Bunodera sacculata Van Cleave \& Mueller, 1932 and B. mediovitellata Tsimbaliuk \& Roitman, 1966 studied by Caira [1].

The presence of six dome-shaped papillae on the rim of the ventral sucker revealed in C. oschmarini has also been observed in C. metoecus by Moravec [7] and in C. opeongoensis by Choudhury \& Nelson [12]. However, no papillae were observed on the ventral sucker in C. farionis [7].

A consistent pattern in the sensory papillae arrangement was found to occur in the anterior body region and ventral forebody surface of all specimens of C. oschmarini. First, there are three paired, symmetrically distributed, differently-sized papillae situated in the centre of the anterior rim of the oral sucker. Such a pattern has not been reported for any of the other Crepidostomum species studied to date by SEM $[1,7,12,13]$. In $C$. metoecus, a species most closely related to C. oschmar$i n i$, only two pairs of symmetrically arranged papillae are visible in the illustrations of Moravec [7] and Žd'árská \& Nebesáŕová [13].

Secondly, a local concentration of eight papillae located ventro-laterally underneath the rim of the oral sucker is characteristic for C. oschmarini. It is worth noting, however, that the presence of a similar but smaller group of papillae can be seen in published SEM photos of some previously studied species, i.e. three papillae in C. metoecus and five papillae in C. cooperi [1].

Thirdly, a single large papilla is associated with each ventro-lateral lobe in $C$. oschmarini. In contrast, the presence of two papillae on the surface of each ventro-lateral lobe is apparent in the SEM photos of $C$. metoecus presented by Moravec [7].

Fourthly, the arrangement of ciliated and non-ciliated sensory endings in two longitudinal symmetrical rows on the ventro-median surface of the forebody was revealed in C. oschmarini. Judging from the available SEM data on the papillae distribution in Crepidostomum spp., two fields of "tegumental bosses" (non-ciliated sensory endings) are situated laterally along the forebody in $C$. metoecus [7] and, there are four pairs of papillae on the ventral forebody in C. opeongoensis [12].

The present SEM study clearly demonstrates the distinction between two sister taxa, C. oschmarini and $C$. metoecus, which have been shown, using our molecular data, to be closely related. This and previous SEM studies on the surface topography of species of Crepidostomum suggest that the arrangement of the sensory endings of adult specimens exhibit interspecific differences which represent useful additional taxonomic criteria for understanding this genus.

\section{Conclusions}

According to available data, we suggest that two complexes of Crepidostomum species parasitize freshwater fishes in Europe. The Crepidostomum metoecus complex consists of C. metoecus (syn. C. nemachilus), C. oschmarini and Crepidostomum sp. 2, while the C. farionis complex includes C. farionis, Crepidostomum sp. 1 and, probably, C. wikgreni. Morphological and molecular evidence together indicated the validity of $C$. oshmarini and provided clear criteria for its separation from C. metoecus and other congeneric species. The phylogenetic study supported that some Crepidostomum species are euryxenous, so host switching in this genus may occur independently of fish-host phylogeny. Our phylogenetic analyses confirm the prediction that there are large numbers of cryptic parasite species to be discovered [59] and reinforce the idea that trematodes are a much more diverse group than as is judged from morphological data and once again confirm the observation that studies based on comparison of nuclear DNA markers are more likely to uncover cryptic species among trematodes than other groups of helminths [60]. This study demonstrates the value of steadily adding relevant parasitological and sequence data to a growing database for allocreadiids as well as for any other group of trematodes. No matter which life-cycle stage has been obtained or from what hosts and geographical localities, from such specimens we will gain the framework needed to connect and clarify life-cycles and gain a more complete understanding of the existing diversity, host specificity and ecology of trematodes under consideration.

\section{Abbreviations}

GTR + G + I: Gamma distribution of rates and a proportion of invariant sites; ITS2: Internal transcribed spacer 2; ML: Maximum likelihood; SEM: Scanning electron microscopy; SPR: Subtree pruning and regrafting

\section{Acknowledgments}

Part of this research was performed in the framework of programme (no. AAAA-A18-118012690100-5) of I. D. Papanin Institute for Biology of Inland Waters, RAS, to L. Poddubnaya and A. Zhokhov. The authors are grateful to the staff of the Centre of Electron Microscopy, I. D. Papanin Institute for the Biology of Inland Waters, for technical assistance. We would like to thank to Dr Eleonora Korol (National Museum of Natural History, NAS of Ukraine) for helping in the collection of clams in the Burulcha River. We are also thankful 
to postgraduate students of Vilnius University (supervisor V. Stunžėnas): Jelena Beliajeva for her contribution in the creation of the new primers, AlJe-F and AlJe-R; and Aurelija Miliūte for her contribution in the molecular analysis of some samples.

\section{Funding}

This research was funded by a grant (no. MIP-43/2015) from the Research Council of Lithuania.

\section{Availability of data and materials}

Nucleotide sequences obtained in the present study have been deposited into the GenBank database under the accession numbers MH143101-MH143119, MH159989-MH159994 (28S) and MH143075-MH143100 (ITS2).

\section{Authors' contributions}

RP designed the study. RP, VS and GS performed the field and laboratory research and analyzed data. AEZ conducted field collections and carried out morphological research. LGP performed micromorphological research. VS and GS extracted DNR for PGR and sequencing. Molecular analyses were carried out by VS. All authors actively contributed to the interpretation of the findings and development of the final manuscript. All authors read and approved the final manuscript.

\section{Ethics approval and consent to participate}

Not applicable.

\section{Consent for publication}

Not applicable.

\section{Competing interests}

The authors declare that they have no competing interests.

\section{Publisher's Note}

Springer Nature remains neutral with regard to jurisdictional claims in published maps and institutional affiliations.

\section{Author details}

${ }^{1}$ Institute of Ecology of Nature Research Centre, Akademijos str. 2, LT-08412 Vilnius, Lithuania. ${ }^{2}$ Papanin Institute for Biology of Inland Waters, Russian Academy of Sciences, Borok, Russia.

\section{Received: 13 April 2018 Accepted: 3 September 2018}

Published online: 28 September 2018

\section{References}

1. Caira JN. A revision of the North American papillose Allocreadiidae (Digenea) with independent cladistics analyses of larval and adult forms Bull Univ Nebr State Mus. 1989:11:1-58.

2. Caira JN, Bogea T. Family Allocreadiidae Looss, 1902. In: Jones A, Gibson DI, Bray RA, editors. Keys to the Trematoda, Volume 2. Wallingford: CABI Publishing and the Natural History Museum; 2005. p. 417-36.

3. Gibson DI. Trematoda. In: Margolis L, Kabata Z, editors. Guide to the Parasites of Fishes of Canada, part IV. Canadian Special Publication of Fisheries and Aquatic Sciences, Vol. 124. Ottawa: NRC Research Press; 1996.

4. Tkach W, Curran SS, Bell JA, Overstreet RM. A new species of Crepidostomum (Digenea: Allocreadiidae) from Hiodon tergisus in Mississippi and molecular comparison with three congeners. J Parasitol. 2013:99:1114-21.

5. Bykhovskaya-Pavlovskaya IE, Kulakova AP. Trematoda. In: Bauer ON, editor. Key to Parasites of Freshwater Fishes of USSR, Volume 3. Leningrad: Nauka; 1987. p. 77-198 (In Russian).

6. Rauckis E. Fish Parasites in Lithuanian Waters. Vilnius: Mokslas; 1988 (In Russian).

7. Moravec F. External morphological differences between Crepidostomum farionis and Crepidostomum metoecus (Trematoda: Allocreadiidae), parasites of salmonids, as revealed by SEM. Folia Parasitol. 2002;49:211-317.

8. Shimazu T. Digeneans parasitic in freshwater fishes (Osteichthyes) of Japan VIII. Allocreadiidae, Crepidostomum. Bull Natl Mus Nat Sci Ser A. 2016;42:107-22.

9. Niewiadomska K. Fish Parasites in Poland (Keys for identification). Digenea. Warszawa: Polskie Towarzystwo Parazytologiczne; 2003 (In Polish).
10. Zhokhov AE, Pugacheva MN. Crepidostomum oschmarini sp. n. (Trematoda Bunoderidae) of Nemacheilus barbatulus (Cobitidae) from the upper Volga River basin. Zool Zh. 1998;77:1329-31 (In Russian).

11. Sokolov SG. Fish parasites of the Upper Volga basin (taxonomic and ecological diversity and zoogeography). Extended abstract of Cand Sci (Biol) dissertation. Moscow: INPA RAN; 2000.

12. Choudhury A, Nelson PA. Redescription of Crepidostomum opeongoensis Caira, 1985 (Trematoda, Allocreadiidae) from fish hosts Hiodon alosoides and Hiodon tergisus (Osteichthyes: Hiodontidae). J Parasitol. 2000;86:1305-12.

13. Žd'árská Z, Nebesářová J. Transmission electron microsopy of presumed sensory receptors of the forebody papillae of Crepidostomum metoecus (Digenea: Allocreadiidae). Folia Parasitol. 2004;51:27-32.

14. Cannon LRG. The life cycles of Bunodera sacculata and B. luciopercae (Trematoda: Allocreadiidae) in Algonquin Park, Ontario. Can J Zool. 1971;49: 1417-29.

15. Brown FJ. On Crepidostomum farionis O.F. Müll. (= Stephanophiala laureata Zeder), a distome parasite of the trout and grayling. I. The life history. Parasitology. 1927;19:86-99.

16. Stenko RP. On the life cycle of Crepidostomum metoecus (Trematoda: Bunoderidae). In: Polyansky Jl, editor. Parasites and Parasitosis of Man and Animals. Kiev: Naukova Dumka; 1982. p. 198-204 (In Russian).

17. Awachie JBE. On the bionomics of Crepidostomum metoecus (Braun, 1900) and Crepidostomum farionis (Müller, 1784) (Trematoda: Allocreadiidae). Parasitology. 1968:55:307-24.

18. Soldánová M, Georgieva S, Roháčová J, Knudsen R, Kuhn JA, Henriksen EH, et al. Molecular analyses reveal high species diversity of trematodes in a sub-Arctic lake. Int J Parasitol. 2017:47:327-45.

19. Stunžènas $V$, Petkevičiūtè $R$, Stanevičiūtè G. Phylogeny of Sphaerium solidum (Bivalvia) based on karyotype and sequences of 165 and ITS1 rDNA. Cent Eur J Biol. 2011:6:105-17.

20. Petkevičiūtè $R$, Stunžènas $V$, Stanevičiūtè G. Differentiation of European freshwater bucephalids (Digenea: Bucephalidae) based on karyotypes and DNA sequences. Syst Parasitol. 2014;87:199-212

21. Bowles J, Blair D, McManus DP. A molecular phylogeny of the human schistosomes. Mol Phylogenet Evol. 1995;4:103-9.

22. Cribb TH, Anderson GR, Adlard RD, Bray RA. A DNA-based demonstration of a three-host life-cycle for the Bivesiculidae (Platyhelminthes: Digenea). Int J Parasitol. 1998:28:1791-5.

23. Scholz T, De Chambrier A, Kuchta R, Littlewood DTJ, Waeschenbach A. Macrobothriotaenia ficta (Cestoda: Proteocephalidea), a parasite of sunbeam snake (Xenopeltis unicolor): example of convergent evolution. Zootaxa. 2013; 3640:485-99.

24. Tkach V, Grabda-Kazubska B, Pawlowski J, Swiderski Z. Molecular and morphological evidences for close phylogenetic affinities of the genera Macrodera, Leptophallus, Metaleptophallus, and Paralepoderma (Digenea, Plagiorchioidea). Acta Parasitol. 1999:44:170-9.

25. Olson PD, Cribb TH, Tkach W, Bray RA, Littlewood DTJ. Phylogeny and classification of the Digenea (Platyhelminthes: Trematoda). Int J Parasitol. 2003;33:733-55.

26. Tkach W, Littlewood DTJ, Olson PD, Kinsella MJ, Swiderski Z. Molecular phylogenetic analysis of the Microphalloidea Morozov, 1955 (Trematoda: Digenea): a bigger data set resolves fewer genera. Syst Parasitol. 2003;56:1-15.

27. Katoh K, Standley DM. MAFFT Multiple Sequence Alignment Software Version 7: Improvements in performance and usability. Mol Biol Evol. 2013; 30:772-80.

28. Posada D. jModelTest: phylogenetic modelling averaging. Mol Biol Evol. 2008;25:1253-6

29. Tamura K, Peterson D, Peterson N, Stecher G, Nei M, Kumar S. MEGA5 Molecular Evolutionary Genetics Analysis using maximum likelihood, evolutionary distance, and maximum parsimony methods. Mol Biol Evol. 2011;24:2731-9.

30. Atopkin DM, Shedko MB. Genetic characterization of far eastern species of the genus Crepidostomum (Trematoda: Allocreadiidae) by means of $28 \mathrm{~S}$ ribosomal DNA sequences. Adv Biosci Biotechnol. 2014:5:209-15.

31. Nybelin O. Crepidostomum suecicum n. sp. - ein Trematode mit ungewöhnlich morphologischer variationsbreite. Ark Zool. 1932;25:1-6.

32. Braun M. Einige bemerkungen über die Fascioliden der Chiroptera. Zool Anz. 1900:23:387-91.

33. Dinulescu G. Bemerkungen über das helminthen-schmarotzertum bei den Salmoniden aus den bergflüssen Rumäniens. Neue arten von Trematoden und Nematoden. An Ins Cercet Pisc României. 1942;1:7-25. 
34. Ślusarski W. The adult Digenea from Salmonidae of the basin of the Vistula and of the South Baltic. Acta Parasitol Pol. 1958;6:247-58 (In Polish).

35. Thomas JD. Studies on Crepidostomum metoecus (Braun) and C. farionis (Muller), parasitic in Salmo trutta L. and S. salar L. in Britain. Parasitology. 1958;48:336-52

36. Linton E. Trematodes from fishes mainly from the Woods Hole region, Massachusetts. Proc US Nat Mus. 1940;88:1-72.

37. Nikol W. Studies on the structure and classification of the digenetic trematodes. Quart J Microscop Sci. 1909;53:391-487.

38. Faust EC. Studies on American Stephanophialinae. Trans Amer Microscop Soc. 1918;37:183-98.

39. Layman EM. Parasitic worms of fish of Baikal Lake. Proc Baikal Limnol Station. 1933:4:5-98 (In Russian).

40. Markewich OP. Parasitofauna of Freshwater Fishes of Ukraine. Kiev: Izdatel'stvo Akademii Nauk SSSR; 1951 (In Russian).

41. Pigulewsky SW. Neue arten von Trematoden aus fischen des Dnjeprbassins. Zool Anz. 1931:96:9-18.

42. Gibson DI, Valtonen ET. A new species of Crepidostomum (Allocreadiidae: Digenea) from north-eastern Finland, with comments on its possible origin. Syst Parasitol. 1988;12:31-40.

43. Bray RA, Foster GN, Waeschenbach A, Littlewood DTJ. The discovery of progenetic Allocreadium neotenicum Peters, 1957 (Digenea: Allocreadiidae) in water beetles (Coleoptera: Dytiscidae) in Great Britain. Zootaxa. 2012;3577:58-70.

44. Petkevičiūtè R, Stunžènas V, Stanevičiūtè G, Sokolov SG. Comparison of the developmental stages of some European allocreadiid trematode species and a clarification of their life-cycles based on ITS2 and 285 sequences. Syst Parasitol. 2010;76:169-78.

45. Poulin R. Evolutionary Ecology of Parasites. 2nd ed. Princeton: Princeton University Press; 2007.

46. Stunžènas $V$, Petkevičiūtè $R$, Poddubnaya $L G$, Stanevičiūtè $G$, Zhokhov AE. Host specificity, molecular phylogeny and morphological differences of Phyllodistomum pseudofolium Nybelin, 1926 and Phyllodistomum angulatum Linstow, 1907 (Trematoda: Gorgoderidae) with notes on Eurasian ruffe as final host for Phyllodistomum spp. Parasit Vectors. 2017:10:286.

47. Brabec J, Waeschenbach A, Scholz T, Littlewood DTJ, Kuchta R. Molecular phylogeny of the Bothriocephalidea (Cestoda): molecular data challenge morphological classification. Int J Parasitol. 2015;45:761-71.

48. Binkienè $\mathrm{R}$, Miliūtè $\mathrm{A}$, Stunženas $\mathrm{V}$. Molecular data confirm the taxonomic position of Hymenolepis erinacei (Cyclophyllidea: Hymenolepididae) and host switching, with notes on cestodes of Palaearctic hedgehogs (Erinaceidae). J Helminthol. 2018; https://doi.org/10.1017/S0022149X18000056.

49. Virbickas J. Fishes of Lithuania. Vilnius: Mokslas; 1986 (In Lithuanian).

50. Tomlinson ML, Perrow MR. Ecology of the Bullhead. Conserving Natura 2000 Rivers Ecology Series No. 4. Peterborough: English Nature; 2003.

51. Hernández-Mena DI, Lynggaard C, Mendoza-Garfias B, Pérez-Ponce de León G. A new species of Auriculostoma (Trematoda: Allocreadiidae) from the intestine of Brycon guatemalensis (Characiformes: Bryconidae) from the Usumacinta River basin, Mexico, based on morphology and 28S rDNA sequences, with a key to species of the genus. Zootaxa. 2016;4196:261-77.

52. Gibson DI. Fauna Europaea: Allocreadiidae, Crepidostomum. Fauna Europaea version. 2018;03. https://fauna-eu.org/cdm dataportal/taxon/d6f4dc06-52914df3-978d-3fad9fod1dfd. Accessed 3 Mar 2018.

53. Krotov Al. Two new species of helminth parasites in vertebrates of Sakhalin Island (Crepidostomum nemachilus sp. n., Heligmosomum petrovi sp. n.). Acta Vet Hungarica. 1959:9:7-12.

54. Wedl C. Anatomische beobachtungen über Trematoden. Sitzungsber. Akad Wiss Math-Naturwiss. 1858;26:241-78.

55. Skryabin Kl, Koval VP. The superfamily Allocreadioidea Nicoll, 1934. In: Skryabin Kl, editor. Trematodes of animals and man and the diseases caused by them, Vol. XXII. Moscow: Nauka; 1966. p. 175-517 (In Russian).

56. Skwortzoff AA. To the anatomy of the trematode Acrolichanus auriculatus (Wedl, 1856) in the sterlet of Volga River basin. Proc Helminthol. 1927;1:276-86.

57. Hopkins SH. The morphology, life histories and relationships of the papillose Allocreadiidae (Trematoda). Preliminary Report. Zool Anz. 1933;103:65-74.

58. Pérez-Ponce de León G, Pinacho-Pinacho CD, Mendoza-Garfias B, Choudhury A, García-Varela M. Phylogenetic analysis using the 28S rRNA gene reveals that the genus Paracreptotrema (Digenea: Allocreadiidae) is not monophyletic; description of two new genera and one new species. J Parasitol. 2016;102:131-42.

59. Pérez-Ponce de León G, Nadler SA. What we don't recognize can hurt us: a plea for awareness about cryptic species. J Parasitol. 2010;96:453-64.
60. Pérez-Ponce de León G, Poulin R. An updated look at the uneven distribution of cryptic diversity among parasitic helminths. J Helminthol. 2017;92:197-202.

61. Shimazu T. Digeneans parasitic in freshwater fishes (Osteichthyes) of Japan. XII. A list of the papers of the series, a key to the families in Japan, a parasite-host list, a host-parasite list, Addenda, and Errata. Bull Natl Mus Nat Sci Ser A. 2017:43:129-43.

62. Curran SS, Tkach W, Overstreet RM. A review of Polylekithum Arnold, 1934 and its familial affinities using morphological and molecular data, with description of Polylekithum catahoulensis sp. nov. Acta Parasitol. 2006;51:238-48.

63. Razo-Mendivil U, Mendoza-Garfias B, Pérez-Ponce de León G, Rubio-Godoy M. A new species of Auriculostoma (Digenea: Allocreadiidae) in the Mexican Tetra Astyanax mexicanus (Actinopterygii: Characidae) from Central Veracruz, Mexico, described with the use of morphological and molecular data. J Parasitol. 2014;100:331-7.

64. Curran SS, Tkach W, Overstreet RM. Phylogenetic affinities of Auriculostoma (Digenea: Allocreadiidae), with descriptions of two new species from Peru. J. Parasitol. 2011;97:661-70.

65. Petkevičiūte $R$, Stunžènas $V$, Stanevičiūtè $G$. Clarification of the systematic position of Cercariaeum crassum Wesenberg-Lund, 1934 (Digenea), based on karyological analysis and DNA sequences. J Helminthol. 2012;86:293-301.

66. Curran SS, Pulis EE, Hugg DO, Brown JP, Manuel LC, Overstreet RM. Phylogenetic position of Creptotrema funduli in the Allocreadiidae based on partial 28S rDNA sequences. J. Parasitol. 2012:98:873-5.

67. Stunženas V, Cryan JR, Molloy DP. Comparison of rDNA sequences from colchicine treated and untreated tissues. Parasitol Int 2004:53:223-8.
Ready to submit your research? Choose BMC and benefit from:

- fast, convenient online submission

- thorough peer review by experienced researchers in your field

- rapid publication on acceptance

- support for research data, including large and complex data types

- gold Open Access which fosters wider collaboration and increased citations

- maximum visibility for your research: over $100 \mathrm{M}$ website views per year

At $\mathrm{BMC}$, research is always in progress.

Learn more biomedcentral.com/submissions 